Halyna Pogrebniak,

Doctor of Study of Art (Dr. Sc.) on specialty Theory and History of Culture,

Associate Professor, Professor of the

Department of Directing and Acting at the National Academy of

Management of Culture and Arts, Kyiv

\title{
РЕЖИСЕРСЬКІ МОДЕЛІ АВТОРСЬКОГО КІНО В СУЧАСНОМУ ФЕСТИВАЛЬНОМУ ПРОСТОРІ \\ Частина 1. Ігрові фільми українських режисерів-авторів у контексті міжкультурної дипломатії
}

\begin{abstract}
Анотація. Розглянуто кінофоруми, які мають значний соціально-економічний потенціал і є потужною складовою культурно-мистецького життя. Визначено місце українських авторських фільмів у міжнародному фестивальному русі. Простежено процес входження вітчизняного авторського кіно у міжнародний фестивальний простір задля розповсюдження інформації про системні зміни в законодавстві щодо підтримки кінематографа; показу спрямованості українського кіномистецтва; демонстрації рівня професійної підготовки кінематографістів; представлення фільмової продукції дистриб'юторам; налагодження кроскультурних зв'язків; зміцнення кінематографічного іміджу України.

Ключові слова: авторський кінематограф, режисер-автор, авторська режисерська модель, кінофестиваль, кроскультурні відносини.
\end{abstract}

Постановка проблеми та актуальність дослідження. Сьогодні функціонування кінофестивалів, зокрема міжнародних, перетворилося на важливу складову соціально-культурного й мистецького життя багатьох держав світу, а це своєю чергою актуалізувало формування цілої низки новітніх моделей їх організації, проведення, фінансування, налагодження дієвих механізмів та інструментів взаємодії з органами управління культурою, громадськими організаціями, потенційними спонсорами й меценатами, засобами масової інформації тощо. Показовим $є$ й той факт, що нині спостерігається специфічний процес стрімкого переформатування фестивальної аудиторії, до складу якої входить дедалі більше вибагливої і водночас освіченої публіки, глядачі з високим рівнем інтелекту, художнім смаком, естетичними вподобання- ми та, як наслідок, високим ступенем вибірковості й вимогливості до екранного продукту. Разом з тим, міжнародні кінофестивалі, що посідають значне місце в процесі налагодження єдиного культурного простору між країнами, $є$ унікальною можливістю співвіднести країну або особистість, невіддільну «від практики, сукупності усвідомлених чи спонтанних практик нації, етносу» (Богуцький... 2013, c. 172) конкретного автора-режисера (спроможного сформувати власну кіномодель і вести міжнародний діалог, формуючи оптимальну модель кроскультурних відносин) зі світом, побачити своє відображення в його картинах.

Mema cmammi. Узагальнити здобутки українських режисерів-авторів у міжнародному фестивальному русі та визначити міжкультурний потенціал українських авторських фільмів. 
Аналіз сучасних досліджень і публікацій. Актуальним проблемам фестивальної діяльності, їх ролі в налагодженні кроскультурних зв'язків та участі в них режисерів-авторів (як митиів з індивідуально-особистісним баченням і відтворенням екранними засобами картини світу, прагненням до новаторства форми, підвищеної складності кінотексту, з намаганням поглибити зміст образів, зосередитись на стилістичних прийомах та здатністю вести оповідь неординарною кіномовою) присвячено значну кількість досліджень, зокрема праці таких теоретиків і практиків екранних мистецтв, як: Л. Бабушка, К. Білокінь, С. Васильєв, А. Гурков, Є. Дейнека, Я. Грановська, Д. Зубенко, П. Жессати, Л. Журавльова, А. Кедбері, О. Кирилова, Т. Клерк, А. Крисальна, О. Овчарук, Б. Периль, О. Першко, А. Плахов, О. Роднянський, С. Слєпак, Ж. Шапрон та інші.

На переконання Л. Казачкової, кінофорум «несе аудиторії інформацію найширшого плану: історичну, моральну, психологічну, соціальну, економічну, наукову, але порівняно з іншими видами мистецтв відображає дійсність із найбільшою реалістичністю і наочністю. Кіно є найбільш точною копією дійсності, фотографічно точного зображення на екрані, сприймається як фрагмент самого життя» (Казачкова, 2014, с. 229).

Цікавими видаються нам і міркування молодої української культурологині Я. Грановської, котра у праці «Кінофестиваль як соціокультурний феномен» доходить висновку, що «репрезентація різними країнами світу своєї кінопродукції на кінофестивалях і $є$, з одного боку, поширенням інформації про спрямованість кінематографа конкретної країни та про рівень професійної підготовки їі кіномитців». Авторка вказує: коли йдеться про можливості фестивального показу, то слід зважити на те, що «країна не лише презентує краще з того, що створене протягом року, а й намагається щонайширше представити фільмовий продукт потенційним, зацікавленим у подальшій співпраці дистриб'юторам, що розповсюджуватимуть певний кінопродукт у світовому прокаті, а отже, кошти, затрачені на виробництво, хоча би частково повернуться виробникам» (Грановська, 2019, с. 120). Крім того, показово, що багатократна реалізація художньо-мистецьких акцій у межах кінофестивалю можлива завдяки введенню в процес міжнародного фестивального руху креативних продуктів культурного труда, котрі виступають тими найважливішими складниками в умовах ринкової економіки (а саме фази збереження благ культури), які сприяють формуванню і збереженню національної спадщини країни. Адже кінофестивалі мають не лише значний соціальний, а й економічний потенціал, завдяки чому можуть приносити певну вигоду не лише безпосереднім організаторам, а й тим містам, регіонам, де їх проводять.

Своєю чергою О. Овчарук зазначає, що кінофестивалі виступають важливим складником «культурної дипломатії», що є «одним із визначальних факторів, що сприяє забезпеченню державних інтересів», з одного боку, будучи продуктом, $з$ іншого - своєрідним «механізмом забезпечення функціонування зовнішньополітичних інструментів, оскільки ії не просто застосовують на всіх рівнях - вона має унікальну здатність формувати думку світової громадськості щодо культури певної держави, іiі національних культурних традицій і загалом культурних стратегій розвитку». У праці «Культурна дипломатія: теоретичний та прикладний аспект» дослідниця доводить, що «саме культурна дипломатія як державна політика у сфері культури має сприяти реалізації різноманітних інформаційних, історико-культурних і просвітницьких проєктів, спрямованих на формування громадянської позиції та національної ідентичності» (Овчарук, 2019, с. 67).

Виклад основного матеріалу. Міжнародні кінофестивалі, виступаючи засобом поширення інформації щодо конкретних подій у тій чи іншій країні (коли за кілька днів можна побачити панораму життя в різних країнах світу), слугують підтвердженням того, що кожна держава сама обирає та презентує певну функціональну значущість того, що відбувається в межах іiї культурної політики як сукупності принципів, механізмів, заходів, спрямованих на створення умов для повноцінного культурного розвитку суспільства на максимально можливе забезпечення основної ролі культури в розвитку самореалізації сутнісних сил людини, гуманізацію суспільства, забезпечення культурних потреб громадян, а ще тієї специфічної царини публічного політичного процесу, що має віддзеркалювати основні принципи й цінності в культурному житті на міждержавному, національному та місцевому рівнях (Карлова, 2011, с. 203).

Нині стрімкий розвиток міжнародного фестивального руху передовсім пов'язаний з тим фактом, що досить велика кількість фільмів (зокрема створених в авторських режисерських моделях), вироблених у всьому світі, котрі становлять певну художньо-мистецьку цінність, не завжди економічно рентабельні й не потрапляють у комерційний прокат, тоді як саме кінофестиваль і стає взаємовигідною (принаймні кінематографістам і публіці) 
нагодою продемонструвати й подивитись такий кінопродукт. Авторським кінематографом, на нашу думку, слід вважати такий, в якому потужно репрезентована постать режисерапостановника, неповторна індивідуальність зі своєю філософією, світоглядом, суб'єктивною системою сприйняття, оцінки, зображення картини світу й образу людини в ній; особистість, здатна представити власну кінематографічну світомодель; спонукати глядача, проникаючи в загальнолюдські проблеми, переінакшувати своє ставлення до реальності, робити спроби трансформувати навколишню дійсність.

Разом $з$ тим, ведучи мову про кінематографічну світомодель, вкажемо, що фільм як модель проходить уявну стадію задуму та їі вербальне втілення в кіносценарії і постає матеріально реалізованою кінематографічною системою, котра, відображаючи чи відтворюючи в певному сенсі об'єкт мистецтвознавчого дослідження, здатна заміщати його так, що вивчення моделі дає нову інформацію про досліджуваний мистецький об'єкт. Своєю чергою авторська (режисерська) кінематографічна світомодель - це засіб, форма пізнання світу режисером, відтворення ним картини світу (з акцентуванням на його індивідуальноособистісному сприйнятті) за допомогою кіномови, основним структурним елементом котрої є кадр. В режисерській моделі авторського кіно суб'єктом моделювання виступає особистість режисера, який демонструє своє світоставлення у художньообразній формі, за допомогою екранної мови, основним культуротворчим елементом якої є кадр. При цьому кінодійсність підкорюється задуму автора, трансформується і набуває форм, відмінних від життєподібних.

На переконання А. Плахова, фестивалі дійсно тривалий час існували у формі доволі елітарної інституції, проте вже наприкінці XX століття стали досить швидко змінюватись. Так, приміром, з'явився кінофорум у Торонто, орієнтований як на широку міську аудиторію, так і на ринок, тоді як Берлінський і порівняно новий Роттердамський також переорієнтувались на міського глядача. Своєю чергою навіть виключно професійний Каннський кінофорум (що дав старт найкращим режисерам авторського кіно - Ф. Фелліні, М. Антоніоні, Ф. Трюффо, А. Рене, А. Вайді, К. Зануссі, О. Іоселіані, А. Тарковському, М. Скорсезе, П. Альмадовару, К. Тарантіно, Л. фон Трієру, Е. Кустуриці, Р. Поланскі, Д. Кроненбергу, І. та Д. Коенам, Д. Лінчу, Т. Кетано й ін.) почав демонструвати комерційну кінопродукцію, щоб створити ажіотаж, привабити публіку, підняти рейтинг. При цьому, зі слів колишнього президента Жиля Жакоба (який, очолюючи з 1976 року престижний фільмовий огляд понад тридцять років, зумів провести його крізь складний перехідний час «від модернізму до постмодернізму і його згасання»), уже наприкінці XX й на початку XXI століття на кінофестиваль стали запрошувати Шерон Стоун і Катрін Деньов, аби завітала публіка, яка б одначасно подивилась і роботи Мануеля де Олівейри чи то Олександра Сокурова, адже масова культура давно стала частиною фестивального організму, серцем якого первісно було мистецтво (Плахов ЭР-б). В одному з інтерв'ю Ж. Жакоб (серед нововведень якого на Каннському кінофорумі з'явились і друга за значимістю після основного конкурсу програма «Особливий погляд»- «Un Certain Regard», що гарантує призерові підтримку у французькому кінопрокаті, і програма підтримки короткометражних (до 60 хвилин) робіт молодих авторів «Cinefondation», з метою стимулювання підготовки молодого покоління кінематографістів) зізнався, що для нього (попри розбіжність думок щодо Канн як столиці гламуру) кіноавтор, постаючи художником, режисером, творцем, завжди залишався головним на кіноогляді. У зв'язку з цим і виникла ідея до 60-ліття вказаного кінофестивалю 2007 року віддати шану визначним режисерам-авторам, які в різні часи брали в ньому участь, надавши можливість кожному зняти короткий фільм, який згодом демонстрували б на кінофорумі в присутності всіх кіноавторів. Виступивши продюсером проєкту, Жакоб діяльність якого, як і час, минули наприкінці XX століття, коли остаточно пішов у небуття класичний кінематограф (Плахов ЭР-б), разом із 36-ма режисерами (а серед них: Такесі Кетано, Жан-П'єр і Люк Дардени, Ітан та Джоел Коени, Алехандро Гонсалес Іньярриту, Акі Каурісмякі, Ларс фон Трієр, Клод Лелуш, Роман Поланскі, Девід Кроненберг, Мануель де Олівейра, Вім Ведерс, Кен Лоуч, Девід Лінч та ін.), які погодились узяти участь у присвяченому пам'яті Федеріко Фелліні альманаху «У кожного своє кіно, або Як завмирає серце, коли гасне світло і починається сеанс», довго шукали тему, котра б об'єднала різних авторів. Такою стала тема кінотеатру, а точніше напівзруйнованої і напівпорожньої кінозали (як своєрідного образу тривоги за долю кіно як мистецтва), адже саме в такому стані нині опинилися переглядові зали, де демонструють авторські фільми (Тыркин ЭР).

Сьогодні, виступаючи одним із найпродуктивніших способів презентації як особистості постановника, так і просування кінопродукції, 
міжнародні кінофоруми є унікальною можливістю для режисера показати свої «фільми широкому колу» як публіки, так і кінематографістів, що прискіпливо оцінюють рівень (як творчий, так і технологічний) фаховості митця, концептуальність його ідей, вартісність філософських меседжів, морально-етичних, естетичних, світоглядних установок. Адже «отримані призи, що для багатьох є просто сатисфакцією, задоволенням певних амбіцій, насправді» спроможні рухати митця далі (Роднянський, 1997, с. 21). На думку К. Зануссі (своєрідного чемпіона світу щодо участі та головування в міжнародних журі), «існує велика різниця між тими призами, котрі не мають жодного значення, окрім престижу, і тими, від котрих може залежати доля, як це буває в Каннах, Венеції або Токіо» (Матизен, 2013б, с. 511). Протилежними є міркування А. Плахова - кінознавця, який на багатьох міжнародних фестивалях працює як голова, член журі чи то програмний директор, котрий опікується відбором фільмів до конкурсу. Він вважає, що в останнє десятиліття в художній політиці Каннського форуму допустили так багато помилок, що перемога в конкурсі зовсім не гарантує ані комерційного успіху, ані місця в історії кіномистецтва. Хоч загалом, переконаний дослідник кіно, престижний кіноогляд, у якому злагоджено працюють ринкові механізми з продажу й купівлі кінопродукту, має репрезентативний вигляд, однак ані представники відбіркової комісії, ані журі нині, на жаль, уже не визначають тенденцій розвитку сучасного кіномистецтва (Плахов ЭР-б). Водночас Андрій Халпахчі, генеральний директор київського МКФ «Молодість» і голова Української фундації, нагадав, що відомий шведський режисер-автор Інгмар Бергман не отримав жодної Золотої пальмової гілки, і лише незадовго до смерті його як найкращого режисера хотіли нагородити почесною Гілкою гілок за вагомий внесок у світове кіномистецтво, проте визнаний майстер відмовився (Ваннек ЕР).

Учасники міжнародних кінофорумів передусім прагнуть щонайширше інформувати кінематографічну громадськість про власні творчі здобутки, про здатність зберігати й розвивати творчі традиції національних кінематографічних шкіл, утверджувати їх престиж на міжнародному рівні, стремління розширювати та зміцнювати в процесі майстеркласів і семінарів професійні зв'язки із закордонними колегами й водночас демонструють жагуче бажання надати об'єктивну інформацію про себе та свою творчість. Однак, на думку А. Звягінцеварежисера-автора, достатньою мірою пошановано- го на міжнародних кінофорумах, - серед деякого числа режисерів $\epsilon$ і такі, хто не бере участі в конкурсах, боячись програти (Матизен, 2013б, с. 654).

Попри чи не домінантну значимість сучасних кінотехнологій, усе ж головною прикметою нинішніх міжнародних кінофестивалів $є$ поновлення тенденції гострого критичного погляду на світ, а також посилення авторського начала, що передовсім відображає набутий життєвий досвід, характер світосприйняття та світовідтворення режисера-постановника - творця власної кіномоделі. Зауважимо, що український авторський кінематограф як складова національної культури містить специфічні особливості у відображенні національного світогляду, постає своєрідним каталізатором його прагнень і ціннісних орієнтирів. До того ж нинішня затяжна криза, що іiї переживає «десята муза» в Україні, є наслідком не лише несприятливих економічних і соціально-політичних умов у країні, а й часом відсутності яскравих і водночас глибоких ідей у висвітленні національної теми, характерів засобами кіно. При цьому держава, як вказує українська культурологиня О. Копієвська, котра «не має потенційної можливості сформувати уявлення про національну культуру як могутній бренд, приречена на постійне утвердження себе у світі». У монографії «Трансформаційні процеси в культурі сучасної України» авторка доводить, що «культурний аспект національного іміджу $є$ незамінним і винятковим, оскільки тісно поєднаний $з$ країною, іiї минулим, духовним і культурним розвитком, тоді як національна культура, іiї бренд у світі, дає змогу визначити унікальність країни» (Копієвська, 2014, с. 252).

Відліком виходу українського кіно (зокрема авторського) в міжнародний культурний простір кінофестивалів слід вважати 1951 рік, коли неігрова стрічка «Квітуча Україна» Михайла Слуцького, демонстрована російською мовою, представляючи радше радянський кінематограф у пафосній оповіді про розквіт народного господарства, науки й культури, натхненну працю українських учених і митців, робітників і селян, здобула на 4-му Каннському кінофестивалі Спеціальний приз журі за короткометражний фільм. При цьому творці стрічки навряд чи вбачали у своїй роботі «інструмент для реалізації національних інтересів» (Овчарук, 2019, с. 67). Створена 1961 року Ялтинською кіностудією культова стрічка «Прощавайте, голуби» режисера Якова Сегеля (події якої відбувались у Києві, на Хрещатику, інших упізнаваних місцях столиці) здобула спеціальну премію FIPRESCI, срібну медаль і почесний диплом на XIV 
МКФ у Локарно, приз «Срібний бумеранг» за режисерську майстерність на ХІ МКФ у Мельбурні, однак навряд чи несла в собі певні національні ознаки, які б репрезентували Україну у світі.

Складно було ідентифікувати з Україною й російськомовну (у чомусь авторську - як суміщення багатьох функцій) стрічку режисера, сценариста й оператора П. Тодоровського «Вірність», фільмовану Одеською кіностудією в Саратові (Росія), представлену 1965 року на МКФ у Венеції та нагороджену почесним призом «За кращий дебют».

Відомим є факт, що того ж 1965 року саме 3 авторського фільму С. Параджанова «Тіні забутих предків», показаного в позаконкурсній програмі кінофоруму в Мар-дель-Платі (Festival Internacional de Cine de Mar del Plata - Аргентина), i нагородження його призами FIPRESCI та «Південним хрестом», а також здобуття низки перемог на інших міжнародних кінофестивалях розпочалася репрезентація у світі безпосередньо українського поетичного (або авторського) кіно, що як складник культурної дипломатії могло би стати ефективним інструментом «державної культурної політики» (Овчарук, 2019 , с. 67), якби не нищення самого мистецького напряму в 1970-х роках.

Знову про український авторський кінематограф (якому наразі й вдається просувати нашу державу у світі) у контексті міжнародного фестивального руху заговорять тільки наприкінці 1980-х, коли фільм Кіри Муратової «Довгі проводи» на МКФ у Локарно 1987 року нагородять призом Міжнародної федерації кінопреси -FIPRESCI. Уже 1990-го на Берлінському МКФ фільм К. Муратової «Астенічний синдром» виборе «Срібного ведмедя». Згодом мисткиню запрошуватимуть на Берлінале неодноразово, де 3 картинами «Три історії», «Лист в Америку», «Другорядні люди», «Довідка» режисерка потрапить у конкурсні й позаконкурсні програми, тоді як 1992 року «Чутливий міліціонер» опиниться в конкурсній програмі Венеційського МКФ, а на Роттердамському форумі 2013-го відбудеться ретроспектива кращих кіноробіт мисткині.

Широкий міжнародний розголос здобула й авторська стрічка Юрія Іллєнка «Лебедине озеро. Зона», фільмована на кіностудії імені О. Довженка, проте коштом іноземних компаній «Video Ukraine Incide» (Канада-США), «Kobza International Corporation» (Канада), «Swea Sov Consult» (Швеція), з їі метафоричним художнім «простором, у поетичній структурі котрого проявлявся внутрішній закон високого авангарду, адже сюжетом стала вже сама граматика мистецтва»
(Sachs, 1991, с. 19). На кінофорумі в Каннах 1990 року вказану роботу, демонстровану в програмі «Quinzaine des ryalisateurs», відзначили як призом молодих критиків «Office franco-allemand pour la jeunesse» (OFAJ), так i FIPRESCI. Того ж року фільм представили й на МКФ у Торонто (Toronto IFF), а також ще на двох канадійських форумах у Монреалі-Montreal IFF, та в Судбері (Онтаріо) Cinefest Sudbury IFF. В одному з інтерв'ю виконавиця головної ролі Людмила Єфименко вказувала, що на кінофорумі в Монреалі представників творчої групи долучили (як і годилось на той час) до радянської делегації та разом запросили на першу пресконференцію. Проте Ю. Іллєнко пояснив, що не лише не бажає висловлюватися російською мовою (через відсутність перекладача української) і послуговуватиметься англійською, а й сміливо заявив, що Радянський Союз до стрічки «Лебедине озеро. Зона» не має жодного стосунку, оскільки кошти на зйомки надала українська діаспора. Показовим було й те, що на знаковій для українського авторського кіно пресконференції режисер-автор повідомив, що представляє на ній передовсім Україну (Бондарчук ER).

Уже 2001 року авторський фільм Ю. Іллєнка «Молитва за гетьмана Мазепу», прем’єра якого (за браком державних коштів демонстрованого 3 монозвуком) відбулась на Берлінале в позаконкурсній програмі, був неоднозначно зустрінутий кіногромадськістю як міжнародною, так і вітчизняною, але водночас таким, що гучно заявив світові про існування українського інтелектуального кіно. Часопис «Кіно-театр» 2003 року опублікував низку таких відгуків на стрічку. Зокрема цікавими видаються міркування академіка В. Скуратівського, який вказував, що фільм потрапив і під своєрідні «ножиці» новонормативної критики, котра вважала, що «тільки вона і знає-відає, яким має бути мистецтво», і водночас «під “ніж” звичайної політичної кон'юнктури, яка тільки прикидається кінокритикою». Автор репрезентував кінотвір, що вперто йде в тому напрямі, який $\epsilon$ цілковитою альтернативою новітній нормативності, оскільки створений «в режимі емоцій, які, здавалося б, уже зникли з великого екрана». Водночас Крістоф фон Маршал назвав стрічку Ю. Іллєнка політичним актом «самовизнання в десяту річницю незалежності» й разом з тим дикою послідовністю містифікацій, що «вводить в оману, майже дурманне зображення сили й насильства, надмірні театральні сцени, розкішні інсценування, що, втім, здаються дешевими підробками через свої несправжні діаманти й позолочений виноград, 
які випромінюють “шарм” пластику». Крім того, дипломатичний кореспондент головної редакції німецької газети «Der Tagesspiege», дорікав режисерові занадто ускладненою операторською роботою, «через яку голова йде обертом», закидав і невиправдану надмірність у демонстрації оголеного тіла, що лише вказує про хибні уявлення українських кінематографістів про «західне кіно сексуальної свободи» (Молитва ЕР). При цьому слід відзначити, що сам Ю. Іллєнко глибоко розумів, якої небезпечної теми й засобів іiї відтворення він торкався в кінокартині, а тому прагнув бути почутим найширшим мистецьким загалом. В одному з інтерв'ю митець зазначав, що намагався вказаним вище фільмом «вчинити найбільший у Європі кіноскандал, щоб луна покотилася земною кулею», втягнувши в нього «максимальну кількість людей» (Брюховецька, Л. 2006a, с. 195). Відзначимо, що чи не найбільший послідовний прибічник авторського поетичного кіно (його режисерської моделі) Ю. Іллєнко довів своєю творчістю, експериментами право на існування цього напряму, вказав його широкі можливості в подальшому розвитку як унікального видовища образів, звуків, барв тощо.

Висновки. Вихід українського кіно (зокрема фільмів представників режисерських авторських моделей) в міжнародний простір свідчить, що певний час (на межі XX-XXI століть) ілюзією українських кінематографістів було переконання в тому, що болючі національні рани зумовлять жвавий інтерес у західноєвропейської публіки, вона одразу забажає співпрацювати 3 нашими митцями й українські фільми купуватимуть і поширюватимуть у світі. Нав'язлива впевненість, що висвітлення лише трагічних сторінок національної історії та, приміром, пострадянського буття приверне особливу увагу міжнародної спільноти до представників українського кіномистецтва, хоч як це прикро констатувати, не зовсім виправдала себе, проте українських авторських фільмів, оптимістичного штибу не стали виробляти більше. У результаті національний кінематограф на деякий час втратив свою досить незначну нішу, що раніше належала радянському кіно, усі ж інші, як виявилося, були зайнятими. Тож для українського й, передовсім авторського, кіно найважчою виявилася здатність знову гідно увійти в міжкультурний простір, довести світовій кіногромадськості, що без українського, зокрема авторського, кіно, підвалини котрого заклав ще О. Довженко й потужно розвинула школа поетичного кіно, кіносвіт у чомусь не повен. А тому актуальними нині вида- ються нам Довженкові щоденникові записи, у яких митець з болем і відчаєм переймається: «Скільки провінціоналізму і тупої самозакоханості, асиміляторів і русифікаторів! О другорядність, яка страшенна сила в тобі!» (Довженко, 1994, с. 262). Таким чином, імовірно, що для створення іміджу України, який би ідентифікував її у світі, на переконання Л. Новікової, «важливо зрозуміти, якою iii бачать народи, якими $є$ вже усталені стереотипи сприйняття нашої країни й нас самих». Дослідниця вказує, що, на жаль, за останній час у міжнародної спільноти виробились досить негативні іміджеві штампи як до самої України, так і до українців. Прикрим є той факт, зазначає авторка, що «Україна на Заході постає як зубожіла країна, де панує корупція, громадяни якої приречені жалюгідно животіти на батьківщині або шукати кращої долі за кордоном, добуваючи хліб насущний продажем власного тіла, зброї й наркотиків» (Новікова, 2009, с. 202-203).

Парадоксально, але нинішній затяжний кризовий стан українського кіновиробництва, з його незначними, як для такої затратної галузі, позитивними зрушеннями з 2017 року, а також ущент зруйнований кінопрокат сприяли прориву вітчизняних режисерів-авторів у міжнародний фестивальний простір, їх появі на престижних кінофорумах класу «А», що дало можливість для «арт-кіна бути оціненим, а для його режисерів - працювати далі, отримуючи для цього не тільки фінансові, а й виробничі, оперативні нагоди» (Роднянський, 1997, с. 21), сприяючи розбудові міжкультурної дипломатії. При цьому додамо, що усвідомлення митцем власної культури та розуміння і вивчення культури інших країн разом з опануванням іноземної мови дає можливість художникові бути гнучким і разом 3 тим зацікавленим та відкритим до іншої етнокультурної дійсності (Бучковська, 2016, c. 153$)$.

\section{Джерела та література}

Богуцький, Ю., Корабльова, Н., Чміль, Г. (2013). Нова культурна реальність як соиіодинамічний процес людинотворення через ролі. Київ: Інститут культурології НАМ України. 272 с

Бондарчук, Л. Актриса Людмила Єфименко: «За свого життя Юрій Іллєнко вірив, що зміни на краще в Україні - не забаряться!» URL:https://zn.ua/ukr/SOCIUM/aktrisa_lyudmila efimenko_za_svogo_zhittya_yuriy_illenko_viriv,_scho_zmini na_krasche_v_ukrayini_ne.html (дата звернення 21.07.2020). Брюховецька, Л. (2006). Кіносвіт Юрія Іллєнка. Київ: Задруга. $288 \mathrm{c.}$

Бучковська, О. Ю. (2016). Міжкультурна компетентність в контексті інтернаціоналізації вищої освіти. Мистецттвознавчі записки: зб. наук. праџь. Вип. 30. Київ: Міленіум. C. $147-155$. 
Ваннек, Л. Андрій Халпахчі про участь Украӥни в Каннах-2010: шанси на перемогу завжди $\epsilon$. URL: https:// www. radiosvoboda. org/a/2039677.html (дата звернення: 22.07.2020).

Грановська, Я. (2019). Кінофестиваль як соціокультурний феномен. Культура і мистеитво: сучасний науковий вимір. III міжн. наук. конф. молодих вчених, аспірантів та магістрів, 5-6 грудня 2019 р. Київ: НАКККіМ. С. 119-120.

Довженко, О. П. (1994). Господи, пошли мені сили: Щоденник, кіноповісті, оповідання, фольклорні записи, листи, документи / упор., вступ. стат. та прим. Р. Корогодського. Харків: Фоліо. 655 с.

Казачкова, Л. (2014). Кіномистецтво як ефективний засіб виховання учнів. Таврійський вісник освіти. № 2 (46). C. $228-230$

Карлова, В. В. (2011). Культурна політика // Філософія: словник-довідник ; за ред.: І. Ф. Надольного, І. І. Пилипенка, В. Г. Чернеця. Київ: НАКККіМ. С. 203-204.

Копієвська, О. Р. (2014). Трансформаційні проиеси в культурі сучасної України: монографія. Київ: НАКККіМ. 296 с.

Матизен, В. (2013). Кино и жизнь. 12 дюжин интервью самого скептического кинокритика: в 2 т. Винница: Глобус-Пресс. Т. 2.831 с.

«Молитва за гетьмана Мазепу». Кіно-Театр. 2003. № 2. URL: https://ktm.ukma.edu.ua/show_content.php?id=84 (дата звернення: 24.07.2020).

Новікова, Л. (2009). Кінематографічний імідж України й українців: західна складова. Науковий вісник Київського національного університету театру, кіно і телебачення імені I. К. Карпенка-Карого: зб. наук. праць. Київ. Вип. 4-5. С. 202-215.

Овчарук, О. (2019). Культурна дипломатія: теоретичний та прикладний аспект. Культурні та мистеиькі студії XXI століття: науково-практичне партнерство: матеріали міжн. симпозіуму, м. Київ, 6 червня 2019 р. Київ: НАКKKiM. C. 67-68.

Плахов, А. «Кинофестивали не вылмут. Они изменятcя». URL: https://newizv.ru/interview/20-06-2018/andreyplahov-kinofestivali-ne-vymrut- oni-izmenyatsya (дата звернення: 24.07.2020).

Роднянський, О.(1997). Три вектори. KINO-KOLO. № 1. С. 21-22.

Тыркин, С. Президент Каннского кинофестиваля Жиль Жакоб: "Тарантино мне отказал, а братьев Коэнов я все же уломал». URL: https:// www. crimea. kp. ru/daily/24071.4/309006/ (дата звернення: 06.03.2020).

Sachs, L. (1991). Soviet lets loose an inspired prison tale in «Swan Lake». Chicago Sun-Times. 1991. June, 7. P. 19.

\section{References}

Bohutskyi, Yu., Korablova, N., Chmil, H. (2013). Nova kulturna realnist yak sotsiodynamichnyi protses liudynotvorennia cherez roli $[\mathrm{New}$ cultural reality as a sociodynamic process of human creation through roles]. Kyiv: Instytut kulturolohii NAM Ukrainy. 272 s. [in Ukrainian]

Bondarchuk, L. Aktrysa Liudmyla Yefymenko: "Za svoho zhyttia Yurii Illienko viryv, shcho zminy na krashche $v$ Ukraini - ne zabariatsia!» Retrieved from: //https://zn.ua/ukr/ SOCIUM/aktrisa_lyudmila_efimenko_za_svogo_zhittya_ yuriy_illenko_viriv,_scho_zmini_na_krasche_v_ukrayini_ne.html.

Briukhovetska, L. (2006). Kinosvit Yuriia Illienka [Yuri Ilyenko’s film world]. Kyiv: Zadruha. 288 s. [in Ukrainian]
Buchkovska, O. Yu. (2016). Mizhkulturna kompetentnist v konteksti internatsionalizatsii vyshchoi osvity [Intercultural competence in the context of internationalization of higher education]. Mystetstvoznavchi zapysky: zb. nauk. prats. Vyp. 30. Kyiv: Milenium. S. 147-155. [in Ukrainian]

Vannek, L. Andrii Khalpakhchi pro uchast Ukrainy $v$ Kannakh-2010: shansy na peremohu zavzhdy ye. [Andriy Khalpakhchi on Ukraine's participation in Cannes-2010: there is always a chance to win]. Retrieved from: https:// www. radiosvoboda. org/a/2039677.html [in Ukrainian]

Hranovska, Ya. (2019). Kinofestyval yak sotsiokulturnyi fenomen [Film festival as a socio-cultural phenomenon]. Kultura $i$ mystetstvo: suchasnyi naukovyi vymir: III mizhn. nauk. konf. molodykh vchenykh, aspirantiv ta mahistriv, 5-6 hrudnia 2019 r. Kyiv: NAKKKiM. S. 119-120. [in Ukrainian]

Dovzhenko, O. P. (1994). Hospody, poshly meni syly [Lord, send me strength]: Shchodennyk, kinopovisti, opovidannia, folklorni zapysy, lysty, dokumenty / upor., vstup. stat. ta prym. R. Korohodskoho. Kharkiv: Folio. 655 s. [in Ukrainian]

Kazachkova, L. (2014). Kinomystetstvo yak efektyvnyi zasib vykhovannia uchniv [Film art as an effective means of educating students]. Tavriiskyi visnyk osvity. № 2 (46). S. 228-230. [in Ukrainian]

Karlova, V. V. (2011). Kulturna polityka [Cultural policy]. Filosofiia: slovnyk-dovidnyk / za red.: I. F. Nadolnoho, I. I. Pylypenka, V. H. Chernetsia. Kyiv: NAKKKiM. S. 203-204. [in Ukrainian]

Kopiievska, O. R. (2014). Transformatsiini protsesy v kulturi suchasnoi Ukrainy [Transformational processes in the culture of modern Ukraine]: monohrafiia. Kyiv: NAKKKiM. 296 s. [in Ukrainian]

Matyzen, V. (2013). Kino i zhizn. 12 dyuzhin intervyu samogo skepticheskogo kinokritika [Cinema and life. 12 dozen interviews of the most skeptical film critic]: v 2 t. Vynnytsa: Hlobus-Press. T. 2. 831 s. [in Russian]

«Molytva za hetmana Mazepu» [«Prayer for Hetman Mazepa»]. Kino-Teatr. 2003. № 2. Retrieved from: https://ktm.ukma. edu.ua/show_content.php?id=84 [in Ukrainian]

Novikova, L. (2009). Kinematohrafichnyi imidzh Ukrainy y ukraintsiv: zakhidna skladova [Cinematic image of Ukraine and Ukrainians: the western component]. Naukovyi visnyk Kyivskoho natsionalnoho universytetu teatru, kino $i$ telebachennia imeni I. K. Karpenka-Karoho: zb. nauk. prats. Kyiv. Vyp. 4-5. S. 202-215. [in Ukrainian]

Ovcharuk, O. (2019). Kulturna dyplomatiia: teoretychnyi ta prykladnyi aspekt [Cultural diplomacy: theoretical and applied aspect]. Kulturni ta mystetski studii XXI stolittia: naukovo-praktychne partnerstvo: materialy mizhn. sympoziumu, m. Kyiv, 6 chervnia 2019 r. Kyiv: NAKKKiM. S. 67-68. [in Ukrainian]

Plakhov, A. "Kinofestivali ne vymrut. Oni izmenyatsya» [ Film festivals will not die out. They will change]. Retrieved from: https://newizv.ru/interview/20-06-2018/ andrey-plahov-kinofestivali-ne-vymrut- oni-izmenyatsya [in Russian]

Rodnianskyi, O. (1997). Try vektory [Three vectors]. KINOKOLO. № 1. S. 21-22. [in Ukrainian]

Tyrkin, S. Prezident Kannskogo kinofestivalya Zhil Zhakob: "Tarantino mne otkazal, a bratev Koenov ya vse zhe ulomal» [Cannes Film Festival President Gilles Jacob: «Tarantino refused me, but I still broke the Cohen brothers».]. Retrieved from: https:// www. crimea. kp. ru/daily/24071.4/309006/ [in Russian]

Sachs, L. (1991). Soviet lets loose an inspired prison tale in «Swan Lake». Chicago Sun-Times. 1991. June, 7. P. 19. [in English] 


\section{Halyna Pogrebniak}

Directing models of author cinema in modern festival space Part 1. Films of Ukrainian directors in the context of intercultural diplomacy

Abstract. Film forums are considered, which have a significant socio-economic potential and are a powerful component of cultural and artistic life. The place of Ukrainian auteur films in the international festival movement has been determined.

The process of entering the director's models of domestic auteur cinema into the international festival space in order to disseminate information about systemic changes in the legislation on cinema support has been traced; showing the humanistic and educational orientation of Ukrainian cinema; demonstrations of the level of professional training of cinematographers; presentation of author's film products to distributors; establishing cross-cultural ties; strengthening the cinematographic image of Ukraine.

Key words: author's cinema, director-author, author's director's model, film festival, cross-cultural relations. 